\title{
Pemecahan Masalah Matematis Siswa Kelas VIII Menggunakan PMRI melalui LSLC pada Materi Gradien
}

\author{
Rio Kurniawan ${ }^{1}$, Ratu Ilma Indra Putri ${ }^{2 *}$, Sunaryati ${ }^{3}$ \\ 1,2Program Studi Pendidikan Matematika, Universitas Sriwijaya \\ ${ }^{3}$ SMP Srijaya Negara Palembang \\ *ratuilma@unsri.ac.id
}

\begin{abstract}
Abstrak
Penelitian ini bertujuan untuk mengetahui bagaimana pemecahan masalah matematis siswa kelas VIII menggunakan PMRI melalui LSLC pada materi Gradien Garis Lurus. Subek yang diambil dari penelitain ini adalah siswa kelas VIII.B di SMP Srijaya Negara dengan jumlah 32 orang siswa. Proses pembelajaran dilakukan sesuai dengan prinsip dan karakteristik PMRI melalui sistem LSLC. Dalam penelitian ini teknik pengumpulan data yang digunakan adalah observasi, tes tertulis dalam bentuk uraian dan wawancara. Obsevasi digunakan untuk melihat kegiatan siswa saat proses pembelajaran berlangsung, tes tertulis digunakan untuk mengetahui bagaimana kemampuan pemecahan masalah siswa dan wawancara dilakukan untuk mendukung jawaban siswa dari soal tes. Berdasarkan hasil penelitian terhadap kemampuan pemecahan masalah matematis siswa menggunakan pendekatan PMRI mellui sistem LSLC di kelas VIII SMP Srijaya Negara, diperoleh kemampuan pemecahan masalah matematis siswa mencapai indikator memahami masalah, merencanakan penyelesaian dan melaksanakan penyelesaian sedangakan indikator yang paling jarang muncul adalah indikator melihat kembali kebenaran soal. Sehingga kesimpulan dari penelitian ini adalah kemampuan pemecahan masalah matematis siswa kelas VIII menggunakan PMRI melalui LSLC pada materi gradien garis lurus dikategorikan cukup.
\end{abstract}

Kata kunci: gradien garis lurus, pemecahan masalah matematis, LSLC, PMRI

\begin{abstract}
This study aims to discover how the mathematical problem-solving ability of students in class VIII using Pendidikan Matematika Realistic Indonesia (PMRI) through Lesson Study for Learning Community (LSLC) on straight-line gradient material. The subjects of this Study were Students of class VIII.B Srijaya State Junior High, totaling 32 students. The learning process takes place adapted to the principles and characteristics of PMRI through the LSLC system. Data collection the techniques used in this study were observation, written tests consisting of two problem descriptions, and interviews conducted to obtain supporting data. The observation was to see student activities during the learning process. The tests are conducted to find out how students mathematical problem-solving abilities. The interview is used to confirm the student's answers. Obtained students' mathematical problem-solving abilities on the Straight-Line Gradient subject and had reached the indicators of understanding the problem, planning solutions, and implementing plans with the most indicators often appear is the indicator of planning a solution. In contrast, the indicator that rarely appears is the indicator of the truth of the completion of the problem. The conclusion of this research is mathematical problem solving of 8th-grade students using PMRI through LSLC on gradient material category was enough.
\end{abstract}

Keywords: gradient, LSLC, mathematical problem solving, PMRI 


\section{Pendahuluan}

Gradien garis lurus adalah materi yang penting untuk di pelajari dan kuasai oleh siswa dalam pembelajaran matematika. selain materi ini tercantum dalam kurikulum 2013, materi ini juga menjadi materi prasyarat yang mendukung materi selanjutnya. Sejalan dengan Sarah Isnaeni, dkk (2018) bahwa materi persamaan garis lurus menjadi materi yang dapat membantu materi matematika berikutnya terutama materi gradien garis lurus, misalnya dalam pembelajaran matematika materi dapat membantu siswa dalam menyelesaikan soal-soal fungsi kuadrat persamaan linear, dan sebangainya. Menurut Wahyuni, dkk (2018) dan Sari, (2011) bahwa salah satu materi penting yang berperan dalam kehidupan sehari-hari yaitu materi gradien dengan contoh seperti membuat grafik dari penjualan barang, kemiringan tangga, dan lain sebagainya.

Namun, pada kenyataannya masih banyak siswa kesulitan dalam menyelesaiakan permasalahan pada materi gradien. Menurut Sumarsih (2016) bahwa kesulitan siswa dalam menentukan gradient atau kemiringan pada persamaan garis lurus disebabkan karena kurangnya kemampuan siswa dalam mencari unsur-unsrur yang diketahui pada soal, cenderung menjawab soal secara terstruktur dan kurangnya konsentrasi dalam menjawab soal. Selain itu, menurut Bariroh, dkk (2018) dan Wahyuni, dkk (2018) mengungkapkan bahwa faktor kesulitan yang dialami siswa juga salah satu diakibatkan proses pembelajaran, yaitu proses pembelajaran yang masih didominasi oleh guru atau bersifat Teacher Centered dan siswa hanya memperhatikan materi yang disampaikan oleh guru. Sedangkan menurut Nusantara (2018) bahwa kurang tepatnya dalam mensetting kelompok secara heterogen dapat mengurangi keoptimalan dan kontribusi siswa dalam pembelajaran matematika, terutama dalam menentukan gradient atau kemiringan garis lurus.

Dalam menentukan gradien garis lurus pada pembelajaran matematika terdapat 7 konsep yang dapat dipakai diantaranya perbandingan geometri, perbandingan aljabar, proferti fisik, proferti fungsional, koefisien parametrik, konsep trignometri, dan konsep kalkulus (Stupm, 1999). Namun, perbandingan geomerti yang paling umum untuk digunakan oleh guru-guru dan lebih mudah di terima oleh siswa dalam menentukan konsep gradien (Nagle \& Moore-Russo, 2013). Sehingga perbandingan geometri menjadi konsep dasar yang dapat mempermudah guru dalam mengajarakan materi kemiringan pada persamaan garis lurus. Sehingga perbandingan geometri menjadi konsep dasar yang lebih tepat untuk digunakan dalam pembelajaran materi gradien garis lurus, dengan bentuk permasalahan yang di gunakan berupa banyaknya penjualan motor dan neraca timbangan. 
Kemampuan pemecahan masalah dapat membantu siswa untuk lebih terbiasa dalam memecahkan soal-soal pemecahan masalah baik itu dalam matematika maupun permasalahan yang terkait dalam kehidupan sehari-hari (Saleh \& Andi (2018; Zulkipli \& Ansori, 2018). Menurut Beck (2005) dan Ollerton (2007) bahwa soal pemecahan masalah adalah soal yang memiliki ciri tersendiri yaitu soal tidak diketahui secara langsung cara penyelesaiannya, soal terbuka atau tidak hanya berfokus pada satu jawaban, dan soal menantang untuk dikerjakan. Oeleh karena itu pentingnya siswa memiliki kemampuan pemecahan masalah. Namun kenyataan masih ada siswa yang kemampuan pemecahan masalahnya masih rendah. Menurut Putra (2018) bahwa rendahkan kemampuan pemecahan masalah menjadikan siswa sulit untuk lebih memahami informasi pada soal, kesalahan dalam menyimpulkan soal, yang diakibatkan oleh kurangnya mengerjakan soal-soal pemecahan masalah

Dalam Kurikulum 2013 yang berkenaan dengan Permendikbud 2016 proses pembelajaran harus di selenggarakan secara interaktif, inspiratif, menyenangkan, menantang, memotivasi, aktif, dan mandiri. Menurut Putri (2014) bahwa dalam memenuhi proses pembelajaran tersebut dibutuhkan pendekatan yang sesuai, yaitu pendekatan PMRI karena pendekatan PMRI berhubungan erat dengan permasalahan kehidupan sehari-hari. Sejalan dengan Idris dan Silalahi (2016) bahwa dalam proses pembelajaran matematika, pendekatan PMRI lebih berfokus pada siswa sehingga siswa mampu menumbuhkan sendiri pengetahuan terhadap masalah yang dihadapinya.

Di abad ke-21 perubahan paradigma pendidikan mengharuskan pembelajaran menguasai 4 soft skills yaitu, berpikir kritis, kolaboratif, kreatif, dan komunikatif (Iswahyud \& Akba, 2018). Kenyataan di lapangan, masih banyak siswa berpusat pada guru dan siswa hanya mendengarkan, mecatat, dan menjawab jika ditanya tanpadi berikan kesempatan untuk aktip dalam berpendapat (Widodo, 2014). Dalam hal ini, menganalisis kemampuan menggunakan model atau pendekatan pembelajaran telah banyak digunakan dalam penelitian antara lain kemampuan representasi menggunakan pendekatan pmri dan LSLC (Adiansyah, 2018), kemampuan berfikir kritis matematis menggunakan model pembelajaran Creative Problem Solving (Wahyuni dkk, 2018), kemampuan representasi matematis menggunakan pendekatan PMRI (Nusantara, 2018), kemampuan penalaran matematis menggunakan pendekatan pmri dan 1slc (Octariana, 2018).

Collaborative learning merupakan kegiatan yang melibatkan semua anggota di setiap kelompok untuk aktif dengan berkerja secara individu dan meminta bantuan kepada teman sekelompoknya jika tidak mengerti "tolong ajari saya" kata yang di gunakan untuk meminta bantuan dan yang di mintai bantuan harus mengajarinya sampai benar-benar paham (Sato, 
2014). Untuk mendukung proses pembelajaran ini, perlunya LSLC. LSLC adalah model pembinaan profesi pendidik melalui pengkajian secara kolaboratif untuk membangun komunitas belajar (Wahdah, 2017). Selain itu, melalui LSLC siswa lebih dapat mengekplor diri karena pembelajaran tidak hanya berfokus pada guru melainkan juga memperhatikan siswa dengan melihat bagaimana ia belajar dan apa yang menjadi dasar pemikirannya dalam situasi nyata (Sato, 2014).

Berdasarkan uraian sebelumnya, peneliti akan menggunakan pendekatan PMRI melalui sistem LSLC yang di dalam sistem LSLC terdapat model Collaborative learning yang dapat membantu siswa menjadi aktip di kelas dengan membuat kegiatan kelompok yang berbeda sehingga, meskipun dengan kegiatan kelompok semua siswa dapat tetap dan lebih mengekplor diri dengan mengeluarkan ide mereka masing-masing.

Berdasarkan pendahuluan tersebut, Peneliti bertujuan untuk mengetahui bagaimana kemampuan pemecahan masalah matematis siswa menggunakan PMRI melalui sistem LSLC. Adapun rumusan permasalahan dari penelitian ini adalah "Bagaimana kemampuan pemecahan masalah matematis siswa kelas VIII menggunakan PMRI melalui LSLC pada materi gradien?"

\section{Metode}

Jenis penelitian ini adalah Deskriptif. Subjek dalam penelitian ini adalah siswa kelas VIII.b di SMP Srijaya negara dengan jumlah 32 orang siswa. Adapun teknik pengumpulan data yang digunakan adalah Observasi, soal tes dan wawancara. Observasi yang digunakan melalui dua cara yaitu rekaman video dan aktivitas siswa saat pembelajaran berlangsung. Dari dua cara observasi ini juga dilakukan bukan hanya untuk melihat cara guru mengajar tetapi juga memperhatikan siswa dari cara belajarnya dikelas, dasar pemikirannya, dan melihat bagaimana cara guru membantu siswa dalam proses pembelajaran (Sato, 2014). Tes tertulis dilakukan secara individu yang bertujuan untuk melihat kemampuan pemecahan masalah siswa setelah mengikuti pembelajaran matematika dengan pendekatan PMRI melalui sistem LSLC. Setelah pembelajaran dan pemberian soal tes kepada siswa, peneliti melakukan pemeriksaan dari hasil jawaban siswa dengan melakukan analisis dan perhitungan berdasarkan pedoman penskoran kemampuan pemecahan masalah matematis siswa. Skor minimal untuk setiap indikator adalah 0 dan skor maksimal untuk indikator satu, tiga, dan empat adalah 4 sedangkan untuk indikator tiga adalah 3. Jika siswa mendapat skor 4 dari setiap indikator soal maka dapat dikatakan siswa telah memunculkan indikator kemampuan pemecahan masalah matematisnya. Namun, jika siswa mendapat skor 3 dan 2 dari setiap indikator maka dapat dikatakan siswa telah memunculkan kemampuan pemecahan masalah matematisnya namun belum maksimal. 
Sedangkan, jika siswa mendapat skor 0 dan 1, dapat dikatakan siswa masih belum mampu memuncukan kemampuan pemecahan masalah matematisnya. Sehingga, peneliti menentukan kemunculan kemampuan pemecahan masalah matematis siswa melalui skor 4,3,2 dari setiap indikator pada soal jumping task dan tes yang diperoleh.

Wawancara dilakukan untuk menambah informasi mengenai soal tes, yaitu untuk mengetahui lebih lanjut proses siswa saat menyelesaikan soal tes yang diberikan. Wawacara yang digunakan yaitu semi struktur.

\section{Hasil Penelitian}

Penelitian ini di laksanakan pada tanggal 19 Agustus 2019. Pada tahap plan, peneliti dan guru secara bersama-sama membuat perangkat pembelajaran baru untuk di gunakan dalam pembelajaran. Namun, sebelum didiskusikan kepada guru perangkat pembelajaran telah divalidasi terlebih dahulu oleh Dosen STKIP PGRI Sidoarjo yaitu Dr. Lestariningsih, M. Pd. Berikut komentar saran dan keputusan validasi untuk lembar observasi kegiatan pembelajaran, lembar observasi kegiatan siswa, dan pedoman wawancara. Terlihat pada tabel 1.

Tabel 1. Komentar, saran, dan keputusan validasi

\begin{tabular}{lc}
\hline \multicolumn{3}{c}{ Komentar dan Saran } & Keputusan Revisi \\
\hline \multicolumn{3}{c}{ Lembar Observasi Kegiatan Pembelajaran } \\
\hline $\begin{array}{l}\text { Sebaiknya lembar observasi di lengkapi dengan menulis } \\
\text { objek yang di observasi, revisi sesuai saran dalam naskah. }\end{array}$ & $\begin{array}{c}\text { Sudah direvisi } \\
\text { sesuai saran }\end{array}$ \\
\hline $\begin{array}{l}\text { Sebaiknya lembar observasi di lengkapi dengan menulis } \\
\text { objek yang di observasi, revisi sesuai saran dalam naskah }\end{array}$ & $\begin{array}{c}\text { Sudah direvisi } \\
\text { sesuai saran }\end{array}$ \\
$\begin{array}{l}\text { Perbaiki kata-kata di lembar agar siswa lebih mudah } \\
\text { memahaminya, Pada LKPD } 1 \quad \text { cukup 1 saja } \\
\text { permasalahannya. }\end{array}$ \\
\hline $\begin{array}{l}\text { Pedoman wawancara } \\
\text { revisi sesuai catatan/sran dalam naskah lembar pedoman }\end{array}$ \\
\hline
\end{tabular}

Pada tahap ini terlibat dua orang yang terdiri dari satu guru matematika dan satu orang peneliti. kegiatan plan ini membahas beberapa hal diantaranya yaitu, jumlah pertemuan yang akan dilaksanakan, indikator pembelajaran, serta membahas RPP secara bersama-sama.

Pada tahap Do, guru model melaksanakan pembelajaran sesuai RPP yang telah di rancang secara bersama-sama. Pembelajaran dilakukan seperti pada umumnya yang terdiri dari kegiatan pendahuluan, isi dan penutup. Pada kegiatan pendahuluan, guru membuka pelajaran seperti pada umumnya yaitu menyampaikan apersepsi, dan menyampaikan tujuan pembelajaran dengan posisi tempat duduk berbentuk huruf U. Pada kegiatan inti siswa diberikan dua LKPD 
yaitu sharing task dan jumping task. Pembagian kelompok terdiri dari delapan kelompok dengan 3-4 orang dengan posisi duduk cross di setiap kelompok. Pada kegiatan ini juga, siswa menyimpulkan hasil pembelajaran dan guru menutup pembelajaran seperti pada umumnya. Sedangkan peneliti dan tim lainnya menjadi observer, dimana tugas para obsever yaitu mengamati aktifitas siswa selama proses pembelajaran berlangsung.

Paa tahap see, para observer secara bersama-sama merefleksi pembelajaran yang telah dilakukan dengan menggunakan perangkat pembelajaran yang telah dibuat. Terlihat dari gambar 1 dan gambar 2, adanya diskusi antar siswa di salah satu kelompok yaitu kelompok 1 , dimana salah satu siswa meminta tolong kepada teman sekompoknya untuk mengajarinya dalam memahami permasalahan pada LKPD 1 dan temanya yang dimintai tolong langsung mengajarinya dengan membimbingnya bahkan memintanya untuk langsung menuliskan jawaban yang diarahkan.
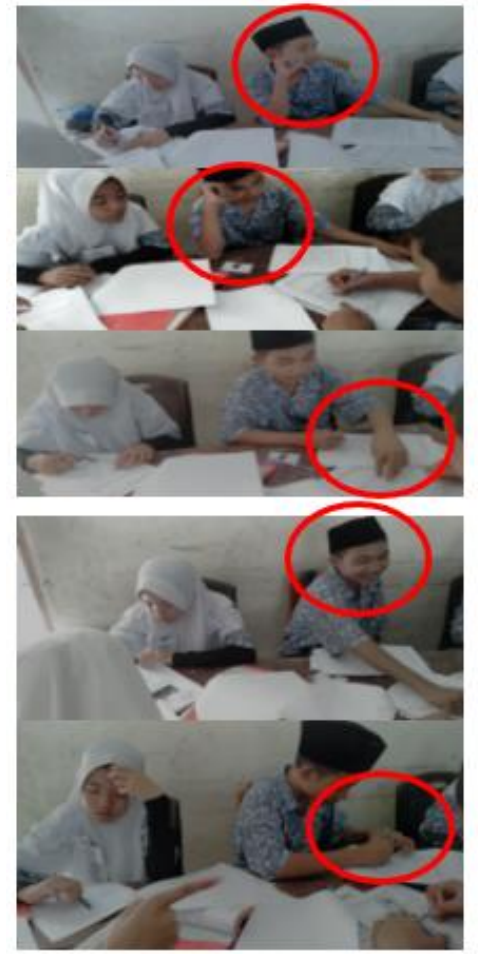

Gambar 1. Ekspresi yang dimunculkan salah satu siswa pada saat mengerjakan soal sharing task b) Isi dan lengkapi tabel di bawah ini dan tentukanlah gradiennya!

\begin{tabular}{|c|c|c|}
\hline $\begin{array}{c}\left.\text { Titik }\left(x_{1}, y_{1}\right)\right) \text { dan } \\
\text { titik }\left(x_{2}, y_{2}\right)\end{array}$ & Bentuk garisnya & jarak sisi tegak \\
\hline & & \\
& & \\
& & \\
& & \\
\hline
\end{tabular}

b) Isi dan lengkapi tabel di bawah ini dan tentukanlah gradiennyal

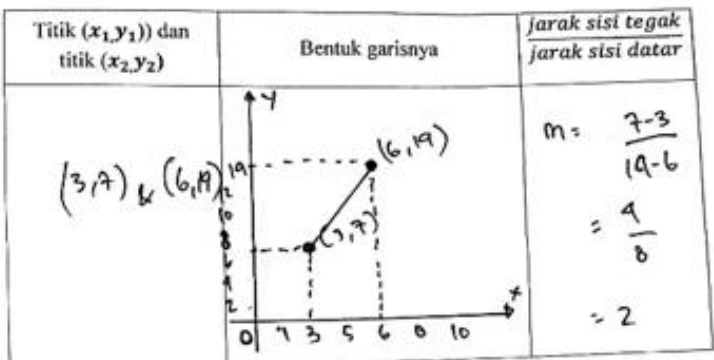

Gambar 2. Matematis yang dimunculkan salah satu siswa pada saat mengerjakan soal sharing task

Tahap re-design, bertujuan memperbaiki perangkat pembelajaran sesuai saran dan masukan dari guru model dan para observer pada saat refleksi. Perbaikan yang dilakukan pada tahap ini yaitu pertanyaan pada soal tes nomor 1 dan 2, yaitu dari kata tentukan kemiringan menjadi tentukan besar kemiringan agar siswa menjadi lebih mudah mengerti pertanyaan yang diberikan. Berikut Rekapitulasi hasil jumping task dan share task serta soal tes pemecahan masalah siswa. 
Tabel 2. Rekapitulasi Hasil Jumping Task dan Tes Pemecahan Masalah Siswa

\begin{tabular}{|c|c|c|c|c|}
\hline & \multirow{3}{*}{ Jumlah siswa yang memenuhi } & \multirow{3}{*}{$\begin{array}{c}\text { LKPD } \\
\text { Jumping } \\
\text { task }\end{array}$} & \multicolumn{2}{|c|}{ Soal Tes } \\
\hline & & & \multicolumn{2}{|c|}{ Nomor Soal } \\
\hline & & & 1 & 2 \\
\hline \multirow{4}{*}{ 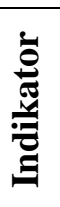 } & Memahami masalah & 26 & 22 & - \\
\hline & Merencakan penyelesaian & 26 & 30 & 26 \\
\hline & Melaksanakan rencana penyelesaian & 19 & 22 & 24 \\
\hline & Melihat kembali kebenaran soal yang dibuat & 11 & 16 & - \\
\hline
\end{tabular}

\section{Siswa ZE (Kategori tinggi)}

\section{Soal jumping task}

Berdasarkan observasi ZE merupakan siswa yang aktif dalam pembelajaran. Siswa ZE merupakan salah satu siswa yang dapat menjawab soal jumping task dengan baik. Dari setiap indikator hanya indikator ke 4 yaitu melihat kembali kebenaran soal yang jawabanya kurang maksimal karena kurang tepat dalam menuliskan kesimpulan sehingga mendapatkan skor 2. Berikut jawaban ZE dari soal jumping task terlihat pada gambar 3.

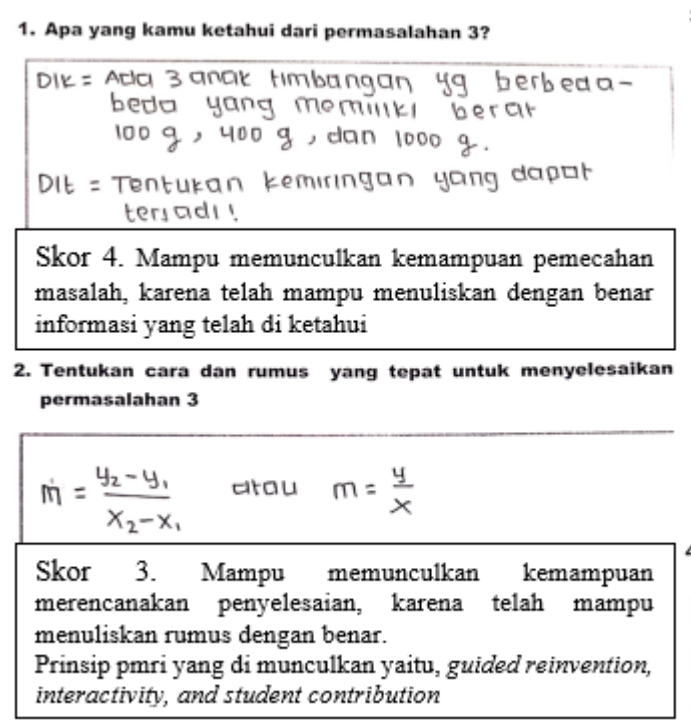

3. Gunakan cara dan rumus tersebut untuk menyelesaikan
permasalahan 3

Gambar 3. jawaban siswa ZE Soal jumping task

Pada indikator 1, siswa ZE mampu menuliskan informasi yang diketahu dan ditanyakan pada soal dengan benar dan tepat, sehingga mendapat skor 4. Pada indikator 2, siswa ZE mampu menuliskan rumus yang akan digunakan dengan benar, sehingga mendapatkan skor 3.pada indikator 3, siswa ZE mampu menyelesaikan permsalahan dengan benar, lengkap dan sistematis, sehingga mendapatkan skor 4. Pada indikator 4, siswa ZE masih kurang mampu menuliskan kesimpulan dengan tepat karena hanya menjawab apa yang tanya dengan benar dan dapat dikatakan belum lengkap, sehingga mendapatkan skor 2. Pada soal jumping task, siswa ZE mendapatkan skor 6 . 


\section{Siswa NPA (Kategori sedang)}

\section{Soal Tes nomor 1}

Pada soal tes nomor 1, siswa NPA merupakan salah satu siswa yang kurang mampu menyelesaikan soal tes nomor 1, terlihat pada saat menyelesaikan permasalahan pada soal masih banyak kesalahan dibuat yang diakibatkan bingung untuk menentukan apa saja informasi yang ketahui dan ditanya serta siswa NPA banyak menghabiskan waktu saat membuat penyelesaiannya meskipun langkah yang ambil dalam menyelesaikan permasalahan sudah benar meskipun belum lengkap. Pada indikator 1, siswa NPA masih belum mampu menuliskan informasi yang dikatehui dan ditanya dengan benar dan tepat, sehingga mendapatkan skor 0 . Terlihat pada jawaban NPA pada gambar 4.

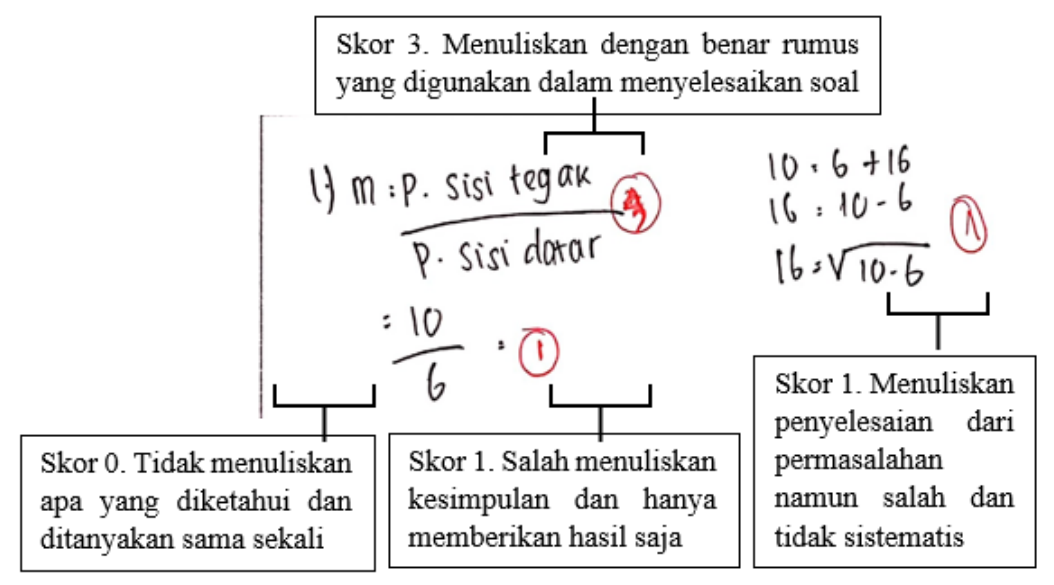

Gambar 4. Jawaban NPA Soal Tes Nomor 1

Hal ini di dukung dengan wawancara peneliti dengan NPA:

Peneliti : ok. Yang di ketahui nya apa NPA?

NPA : kuadrat sisi miring

Peneliti : ok, Kuadrat sisi miring. Nah di sini kan ada yang di ketahui dan di tanya, kenapa tidak dibuat di lembar jawaban?

NPA : bingung Pak

Peneliti : ohh, bingung. Jadi kemarin tidak di tulis karena masih bingung?

NPA :ya Pak.

\section{Siswa MH (Kategori rendah)}

\section{Soal tes nomor 2}

Pada soal tes nomor 2, Siswa MH merupakan siswa yang kurang mampu menyelesaikan soal tes nomor 2, siswa ini juga menjawab sesuai yang dipikirkannya. Karena dalam proses menjawab pun, MH kurang dalam hal diskusi bersama temannya, karena fokus pada lembar jawaban sendiri. Berikut jawaban MH pada soal tes nomor 2, terlihat pada gambar 5 


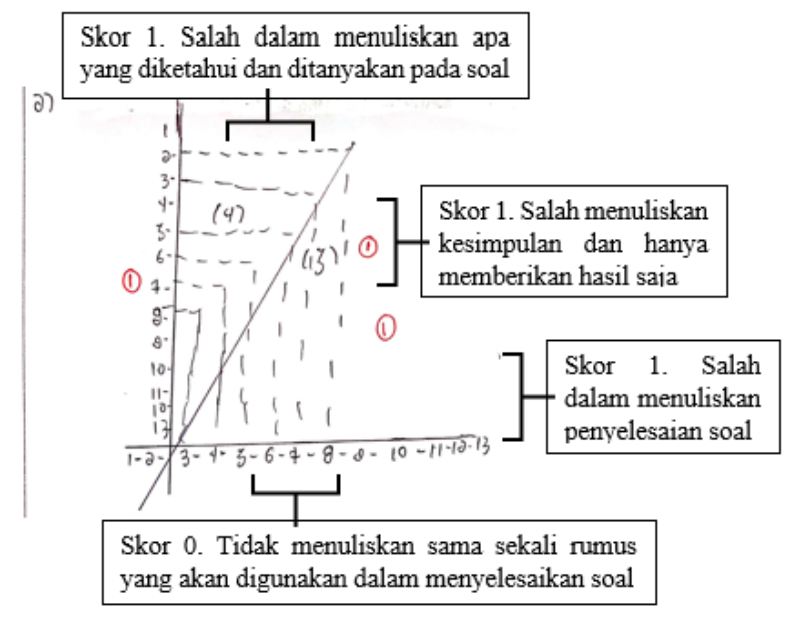

Gambar 5. Jawaban MH Soal Tes Nomor 2

Pada indikator 1, siswa MH kurang mampu menuliskan informasi yang ada pada soal dengan benar, sehingga skor yang diperoleh adalah skor 1. Pada indikator 2, siswa belum mampu memperkirakan langkah yang akan digunakan dengan menuliskan rumus dengan benar yang akan digunakan untuk menyelesaikan soal, sehingga mendapatkan skor 0. Hal ini di dukung dengan wawancara peneliti dengan NPA

Peneliti : untuk nomor 2 ini, kira-kira apa yang diketahui dan di tanya dari soal tersebut? $\mathrm{MH} \quad$ : garis kordinat yang diketahui dan ditanya tentukan kemiringan garis g pada gambar di atas

Peneliti : dari yang diketahui dan ditanya pada soal, apa yang yang dapat di lakukan untuk menyelesaikan soal tersebut?

MH : di sini dapat titik 4 (sambil menunjukkan garis bernilai 4 pada grafik koordinat cartesius yang dibuatnya)

\section{Pembahasan}

Pada tahap awal (plan) yaitu proses dimana penyusunan perangkat pembelajaran yang dilakukan peneliti dan guru secara bersama-sama perangkat pemebelajaran disesuaikan dengan prinsip dan karakteristik PMRI. Sejalan dengan Putri (2012) yang mengatakan bahwa tahap plan ialah proses kolaborasi untuk menyusun perangkat pembelajaran yang berpusat pada siswa. Pada tahap pelaksanaan ( $d o$ ), pada saat kegiatan pendahuluan posisi tempat duduk membentuk huruf U. Sesuai dengan Sato (2014) mengungkapkan bahwa penataan kelas berbentuk huruf $U$ (model seminar) merupakan dasar agar setiap siswa dapat berpartisipasi dalam pembelajaran kolaboratif tanpa terkecuali.

Pada kegiatan inti pembelajaran, setelah siswa duduk disetiap kelompoknya, guru memberikan LKPD kepada seluruh siswa yaitu soal jumping task dengan konteks penjualan motor dan share task dengan konteks neraca timbangan. Hal ini sesuai yang kemukakan oleh Zulkardi \& Putri (2010), bahwa karakteristik yang pertama pada PMRI yaitu menggunakan 
masalah kontekstual sebagai titik start dalam pembelajaran. Pada kegiatan ini juga, guru selalu memberikan pengertian kepada seluruh siswa untuk meminta tolong kepada teman sekolompoknya jika pada saat mengerjakan LKPD merasa kesulitan dan guru juga bertujuan agar siswa berkolaborasi pada saat pembelajaran berlangsung. Pada bagian mengerjakan LKPD jumping task, lebih setengah dari siswa mengalami kesulitan dalam menyelesaiakan permasalahan yang diberikan. Namun, hal ini berarti soal Jumping task berhasil, sejalan dengan Sato (2014) bahwa keberhasilan soal jumping task dapat dilihat melalui sebagian siswa yang dapat mengejakan soal dengan benar. Kemudian guru memberikan soal tes kepada siswadan di analisis untuk mengetahui kemunculan indikator kemampuan pemecahan masalah pada pembelajaran PMRI melalui sistem LSLC.

Dari data yang di hasilkan, indikator yang paling sering muncul adalah indikator merencakanan penyelesaian soal. Kemunculan indikator ini lebih sering muncul dibanding dengan indikator lainnya di semua soal. Hal ini disebabkan oleh kemampuan peserta didik sudah sudah cukup baik dalam merencanakan penyelesaian terhadap materi kemiringan dengan membuat rumus kemiringan sesuai yang butuhkan. Selain itu, hal ini disebabkan siswa terlatih dengan memahami konsep kemiringan melalui pengerjaan LKPD shaing task dan jumping task. Sedangkan untuk indikator yang paling jarang muncul adalah indikator melihat kembali dengan manarik kesimpulan pada soal jumping task dan soal tes nomor 1 dan nomor 2. Berdasarkan hasil wawancara yang telah dilakukan, faktor kendala yang dialami siswa yaitu tidak memilki cukup waktu dan masih bingungnya siswa dalam membaca soal karena tidak selesainya membaca soal sehingga siswapun kurang memahami maksud dari soal.

Pembelajaran melalui PMRI dan LSLC secara tidak langsung membantu siswa untuk dapat meningkatkan kemampuan pemecahan masalah matematis siswa. Sehingga pembelajaran matematika menggunakan PMRI dan LSLC dapat diterapkan di sekolah.

\section{Simpulan}

Kemampuan pemecahan masalah matematis siswa di kelas VIII menggunakan PMRI melalui LSLC pada materi gradien garis lurus telah mencapai indikator memahami masalah, merencanakan penyelesaian, dan melaksanakan rencana penyelesaian dengan indikator yang paling sering muncul adalah indikator merencanakan penyelesaian sedanga indikator yang paling jarang muncul adalah indikator memeriksa kembali kebenaran soal. 


\section{Referensi}

Bariroh, N. M., Triyanto, \& Setiawan, R. (2018). Eksperimentasi model pembelajaran cooperatif think talk write dengan pendekatan scientific pada materi PGL ditinjau dari gaya berpikir siswa kelas VIII SMP Negeri 17 Surakarta. Jurnal Pendidikan Matematika dan Matematika (JPMM). 2(4), 289-290.

Idris, I., \& Desri, K. S. (2016). Penerapan pendekatan PMRI untuk meningkatkan kemampuan penyelesaian soal cerita pada kelas VII A SMP UTY. Jurnal Edumatsains, 1(1), 73-82.

Iswahyud, D., \& Akba, M. R. (2018). Peningkatan kemampuan komunikasi mahasiswa melalui metode student team achievement division berbasis LSLC. Jurnal Ilmiah Pendidikan Matematika, 8(1), 13-15. https://doi.org/10.21067/jip.v8i1.2174.

Nagle, C. \& Moore, R. D. (2013). The concept of slope: comparing teachers concept images and insructional content. Inverstigation In Mathematics Learning, 6(2), 3-5. https://doi.org/10.1080/24727466.2013.11790330.

Nusantara. (2018). Kemampuan representasi matematis siswa pada pokok bahasan gradien garis lurus menggunakan pendekatan PMRI di SMP N 13 Palembang. Indralaya: UNSRI.

Putra, H. D., Thahiram, N. F., Ganiati, M., \& Nuryana, D. (2018). Kemampuan pemecahan masalah matematis siswa SMP pada materi bangun ruang. Jurnal Ilmiah Pendidikan Matematika, 6(2), 82-84. https://doi.org/10.25273/jipm.v6i2.2007.

Putri, R. I. I. (2012). Implementasi lesson study melalui pendekatan PMRI pada mata kuliah metode statistika I. KNMXVI, 1-8.

Saleh, A., \& Lubis, F. A. (2018) Pengaruh penggunaan model pembelajaran make a match terhadap kemampuan pemecahan masalah materi pokok SPLDV di Kelas VIII SMP N 1 Batang Angkola. Jurnal Education and Development IPTS, 6(1), 20-26.

Sari, N. (2011). Pengembangan materi ajar PGL menggunakan pendekatan PMRI di Kleas VIII SMP. Indralaya: UNSRI.

Sato, M. (2014). Dialog dan kolaborasi di SMP Praktek “Learning Community”. Jepang: JICA.

Sato, M. (2014). Mereformasi sekolah: konsep dan praktek komunitas belajar. Jepang: JICA.

Sumarsih. (2016). Analisis kesulitan siswa SMP dalam mempelajari PGL dan alternatif pemecahannya. Prosiding Seminar Matematika dan Pendidikan Matematika, 415-418.

Stump, S. (1999). Secondary mathematic teachers knowledger of slope. Mathematics Education Reasearch Journal, 11(2), 124-144. https://doi.org/10.1007/BF03217065.

Wahdah, A. H. (2016) Metode bermain peran dengan menggunakan lesson study (guru mitra) sebagai model pembelajaran matematika kelas XII IPA 2 SMA N 1 Guntur. Jurnal Profesi Keguruan, 3(1), 26-28.

Wahyuni, R., Marriyam, \& Sartika, D. (2018). Efektivitas model pembelajaran creative problem solving dalam meningkatkan kemampuan berfikir kritis matematis siswa pada materi PGL. Jurnal Pendidikan Matematika Indonesia, 3(1), 26-27. https://doi.org/10.26737/jpmi.v3i1.520.

Widodo, M. S. (2014). Keefektifan pembelajaran matematika dengan pendekatan PMRI pada materi lingkaran di kelas VIII SMP. Jurnal Ilmiah Pendidikan Matematika, 3(3), 125128.

Zulkardi, \& Putri, R. I. I. (2010). Pengembangan blog support untuk membantu siswa dan guru matematika Indonesia belajar PMRI. JIPP Balibang, 4-6.

Zulkipli, \& Ansori, H. (2018). Kemampuan pemecahan masalah matematis siswa SMP Muhammadiyah 1 Banjarmasin. Jurnal Pendidikan Matematika, 6(1), 34-36. https://doi.org/10.20527/edumat.v6i1.5118. 